\title{
Peningkatan Kuantitas dan Kualitas Produk Keripik Talas dan Singkong pada Kelompok Industri Rumah Tangga Melalui Program Kemitraan Masyarakat (PKM)
}

\author{
Hena Dian Ayu ${ }^{1)}$, Wignyo Winarko ${ }^{1)}$, Akhmad Jufriadi ${ }^{1)}$ \\ ${ }^{1)}$ Universitas Kanjuruhan Malang
}

\begin{abstract}
ABSTRAK
Tujuan pengabdian ini adalah untuk meningkatkan kualitas dan kuantitas produksi kripik umbi singkong dan umbi talas melalui alih tekhnologi dan pelatihan management produksi hingga pemasaran. Metode yang digunakan untuk mencapai tujuan tersebut adalah dengan menggunakan demostrasi, ploting dan evaluasi ketercapain Program Kemitraan Masyarakat (PKM) kepada mitra yaitu kelompok industri rumah tangga. Hasil dari pengabdian ini menunjukkan bahwa alih tekhnologi berupa penggunaan perajang otomatis mampu menghemat tenaga, waktu dan selisih umbi rajang yang dihasilkan yaitu $35 \mathrm{~kg} / \mathrm{jam}$. Penggunaan spinner peniris minyak mampu meniriskan tiga kali lipat dibanding menggunakan peniris tradisional. Secara umum dapat disimpulkan bahwa program pengabdian ini mampu meningkatkan kuantitas dan kualitas produksi keripik, sehingga omset mitra pengabdian dapat meningkat.
\end{abstract}

\section{Kata Kunci : Kuantitas, Kualitas, Produk, Kripik}

\section{ABSTRACT}

The purpose of this service is to improve the quality and quantity of cassava and taro tuber production through the transfer of technology and production management training to marketing. The method used to achieve this goal is to use demonstration, ploting and evaluation of the achievement of the Community Partnership Program (PKM) to partners, namely the home industry group. The results of this dedication showed that the transfer of technology in the form of automatic chopper was able to save energy, time and the difference in the yield of chopped tubers which was $35 \mathrm{~kg} / \mathrm{hour}$. The use of oil-spinner spinner is able to drain three times compared to using traditional slicer. In general, it can be concluded that this service program is able to increase the quantity and quality of chips production, so that the service partner's turnover can increase.

Keywords : Keywords: Quantity, Quality, Products, Chips 


\section{PENDAHULUAN}

Kabupaten Malang merupakan daerah dengan pertanian yang cukup maju, sehingga banyak masyarakatnya yang mempunyai usaha terutama di bidang kuliner menggunakan bahan dasar dari hasil pertanian, seperti kripik dari singkong. Kelompok mitra dari Program Kemitraan Masyarakat (PKM) ini adalah dua kelompok Pengolah Keripik Singkong yang belum produktif secara ekonomis tetapi memiliki hasrat kuat untuk terus mengembangkan usahanya dan menjadi wirausahawan. Namun, untuk meningkatkan kualitas produksi dan manajemen usahanya, mitra masih membutuhkan bimbingan dan sentuhan IPTEK untuk meningkatkan kualitas dan kuantitas produksi keripik singkongnya. Dari hasil observasi dan diskusi yang dilakukan pada tanggal 13 April 2017 dapat diketahui bahwa usaha pengolahan kripik singkong ini memiliki beberapa kekurangan dan keterbatasan dalam rangka pengolahan produksi dan pengembangannya. Hal ini terjadi karena berbagai keterbatasan yang dimiliki oleh kelompok mitra dan pengelolaan yang amat sederhana. Pencacahan singkong, penjemuran, perendaman, penepungan bumbu, pengemasan dan pemasaran masih dilakukan dengan sederhana. Produksi kripik singkong dengan menggunakan teknologi belum dilakukan, sehingga usaha pengembangan dan peningkatan produksi kripik singkong dari segi kualitas dan kuantitas masih rendah. Secara umum permasalahan yang dihadapi kedua mitra adalah masalah produksi, pengemasan, pemasaran, pengolahan limbah, dan manajemen keuangan.

Tempat produksi masih belum memperhatikan kebersihan dan proses produksinya masih dilakukan secara tradisional. Misal dalam teknik pengupasan singkong, alat pengupas masih dilakukan secara manual dengan menggunakan pisau dapur seperti yang ditunjukkan pada Gambar 1. Akibatnya proses produksi menjadi sangat lama, rawan dengan kecelakaan kerja yang mengakibatkan jari-jemari tangan mudah tersayat.

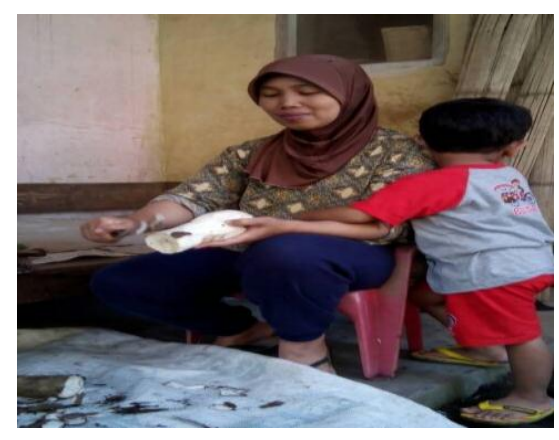

Gambar 1. Proses pengupasan singkong dengan pisau dapur 
Pada proses pencacacahan, mitra menggunakan alat pencacah serut sederhana. Sehingga hasilnya juga belum maksimal baik dari segi kualitas maupun kuantitas. Penggunaan alat pencacah satu bentuk mata pisau juga menghasilkan bentuk kripik singkong yang monoton dan tidak terstandar. Selain itu alat ini sangat berbahaya karena juga bisa mengakibatkan tangan tersayat, seperti pada Gambar 2.

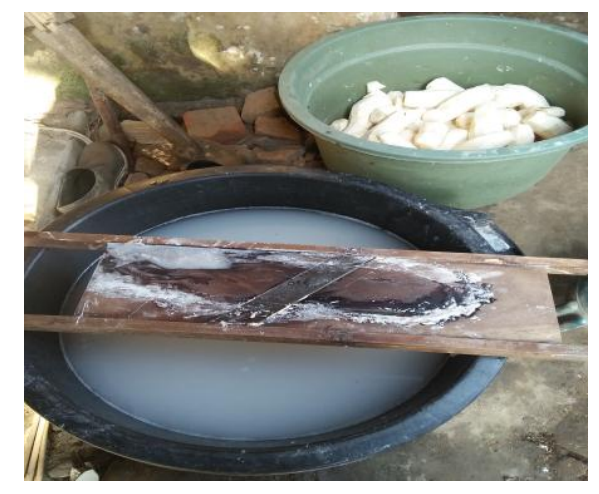

Gambar 2. Proses pencacahan singkong secara sederhana

Proses pencacahan yang sangat sedrhana sangat tidak memungkinkan untuk meningkatkan kualitas produksi dari segi kuantitas karena butuh waktu yang lama dan dari segi kualitas juga tidak terlalu bersih dan higienis. Kondisi alat yang sudah usang, agak karatan, proses pengerjaan menggunakan sarung tangan yang kotor dan kondisi tempat yang lembab yang berdampak pada rentannya timbul penyakit. Sistem pengeringan masih mengandalkan panas matahari sehingga waktu pengeringan lebih lama, apa lagi wilayah Malang termasuk daerah yang sering hujan, dampaknya terjadi penurunan produksi baik dari segi kualitas maupun kuantitasnya. Ukuran singkong yang tidak seragam mengakibatkan waktu pengeringan juga tidak seragam sekitar 4-6 hari, cara penjemuran singkong masih tradisional, yaitu singkong setelah dicacah langsung dibiarkan/dijemur di depan jalan rumah tanpa ada alas yang bersih sehingga singkong mudah berjamur, warnanya kehitam-hitaman dan terkontaminasi. Bahkan terkadang jika cuaca tidak mendukung dilakukan penjemuran karena mendung, pengrajin camilan langsung dimasukkan dalam tangki penggorengan sehingga menurunkan kualitas produksi. Penggunaan minyak yang terus menerus tanpa penggantian semakin menurunkan kualitas dari kripik singkong yang dihasilkan. seperti pada Gambar 3. Selain itu juga jenis dan bentuk kripik masih monoton, mitra belum mapu membuat camilan aneka bentuk, rasa, dan warna yang sesuai permintaan konsumen. 


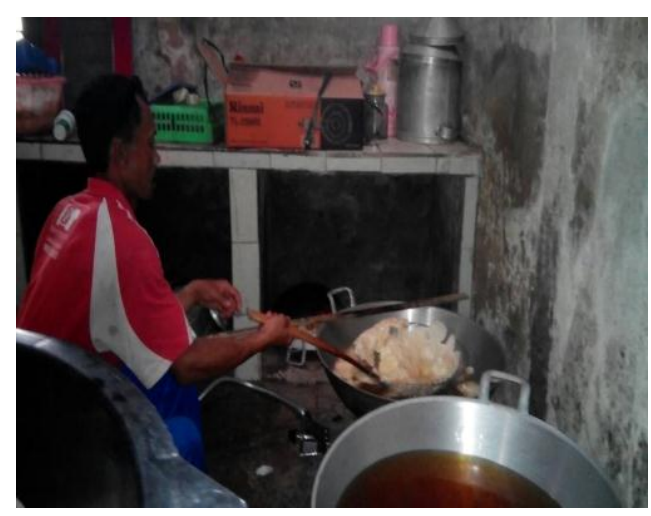

Gambar 3. Proses penggorengan dan penirisan minyak kripik singkong

Hasil produksi keripik singkong langsung dijual ke pasar terdekat oleh mitra dengan model curah tanpa proses pengemasan yang memadai sehingga mudah terkotori oleh debu, polusi kendaraan, bau limbah dan kotoran hewan-hewan kecil seperti cicak dan serangga dampaknya camilan tidak higienis, mudah rusak, remuk dan tidak menarik, seperti Gambar 4. Adapun hasil yang dijual dan dikemas sederhana yang diklip dengan menggunakan sulut api tanpa disertai label yang menarik, tidak ada tulisan kadar gizi, tidak ada petunjuk kadaluarsa, cara penyimpanan produk juga belum disajikan secara rapi. Sehingga konsumen kurang tertarik dan berminat terhadap produksi kripik singkong dan produk sulit diterima di pasar, karena produk sebagian sudah rusak atau remuk sebelum ada ditangan pelanggan.

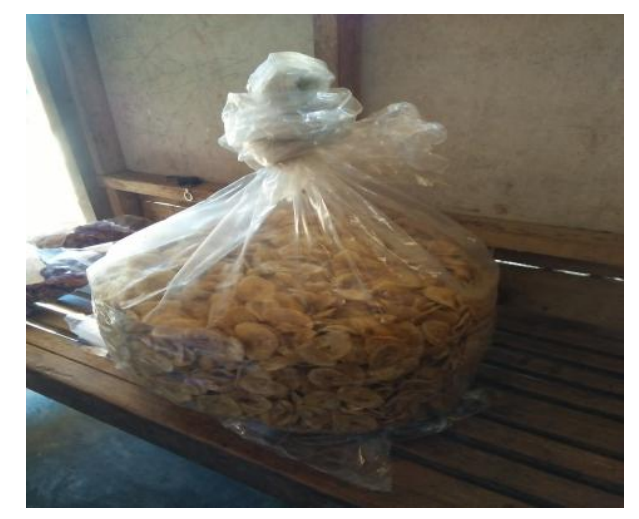

Gambar 4 Pengemasan kripik singkong ala kadarnya

Pemasaran produk oleh mitra dilakukan dengan cara tradisional yaitu dijual eceran ke tetangga untuk camilan dengan kemasan plastik biasa dan dijual ke pasar-pasar Malang dengan kemasan plastik besar, serta sebagian kecil dijual ke toko kelontong atau pasar Malang. Hasil olehan masih mengalami kesulitan masuk ke swalayan karena di swalayan mensyaratkan produk terstandar, yang dilengkapi ijin kesehatan, perdagangan dan kehalalan. Sarana promosi yang dilakukan masih sebatas dari mulut kemulut pelanggan. Disamping itu 
belum ada pemasaran melalui on line. Limbah produksi kripik singkong yang dihasilkan belum diolah dengan baik, Adapun limbah yang dihasilkan dari kegiatan produksi kripik singkong ini diantaranya kulit singkong, tanah yang menempel pada umbi, sisa rendaman dan cucian singkong yang dibuang begitu saja. Hal yang sudah dilakukan oleh kelompok usaha kripik singkong ini secara umum kulit singkong ditumpuk di luar rumah dan dibiarkan mengering begitu saja. Bila sudah mengering biasanya dibakar dan dapat menimbulkan asap. Namun yang terjadi adalah kulit yang masih basah ini sulit mengering karena tingginya tumpukan sehingga cahaya matahari sulit menembus bagian bawah tumpukan kulit, apalagi saat musim penghujan dimana cahaya matahari sangat sedikit yang mengenai limbah. Akibatnya lapisan bagian bawah menjadi tetap basah dan mudah mengalami pembusukan yang menimbulkan bau tidak sedap.

Manajemen keuangan yang dilakukan mitra masih menggunakan manajemen "kantong" artinya uang untuk pembelian dan hasil penjualan camilan hanya keluar masuk saku, tanpa ada pencatatan yang jelas, sehingga sering kali dijumpai mereka kehilangan modal dan terkadang malah hutang ke "Koperasi atau Bang Renten" dengan bunga yang tinggi untuk melanjutkan proses produksinya, karena modal usaha dipakai keperluan lain. Dampaknya adalah produksi yang bisa terhenti sewaktu-waktu karena kehabisan modal. Jika masalah yang dihadapi pengolah kripik singkong ini dibiarkan dan tidak ada upaya untuk segera menyelesaikan, maka akan dapat mengakibatkan permasalahan, antara lain: a) Kualitas dan kuantitas produk olahan camilan menjadi semakin rendah, kalah bersaing dengan produk daerah lain, dan tidak laku. b) Jika produk tidak laku, maka usaha olahan kripik singkong akan tutup, dan dapat memunculkan pengangguran-pengangguran baru dan tentunya akan berdampak terhadap permasalahan sosial masyarakat. Berdasarkan permasalahan di atas, perlu ada upaya untuk membantu menyelesaikan masalah yang dihadapi kelompok pengolah kripik singkong ini, dengan harapan mampu menggiatkan wirausaha di daerah Malang untuk meningkatkan pendapatan masyarakat dan mengurangi pengangguran.

\section{METODE}

Metode yang digunakan pada pelaskanaan program pengabdian ini, disesuaikan dengan permasalahan yang dihadapi mitra, Sebagaimana tampak pada tabel 1. 
Tabel 1. Metode Pelasanaan Program Pengabdian Kepada Masyarakat

\begin{tabular}{|c|c|c|c|c|c|}
\hline No & Permasalahan & $\begin{array}{l}\text { Metode dan } \\
\text { Pendekatan }\end{array}$ & $\begin{array}{c}\text { Solusi yang } \\
\text { Diatawarkan }\end{array}$ & Peran Mitra & $\begin{array}{l}\text { Hasil yang } \\
\text { diharapkan } \\
\text { (spesifikasi) }\end{array}$ \\
\hline \multirow[t]{2}{*}{1.} & $\begin{array}{l}\text { Produksi: } \\
\text { a) pencacahan } \\
\text { singkong } \\
\text { menjadi bahan } \\
\text { setengah kurang } \\
\text { efektif, dan } \\
\text { kurang higenis } \\
\text { terlalu besar / } \\
\text { terkadang } \\
\text { ketebalan tidak } \\
\text { merata sehingga } \\
\text { sulit kering }\end{array}$ & $\begin{array}{l}\text { Pengadaan/pe } \\
\text { mbuatan alat } \\
\text { pencacah } \\
\text { singkong, } \\
\text { dan pelatihan } \\
\text { atau } \\
\text { demonstrasi } \\
\text { penggunanny } \\
\text { a }\end{array}$ & $\begin{array}{l}\text { Pengadaan alat } \\
\text { produksi/penca } \\
\text { cah singkong } \\
\text { dan } \\
\text { demonstrasi } \\
\text { cara } \\
\text { penggunaanny } \\
\text { a) }\end{array}$ & $\begin{array}{l}\text { menyediakan } \\
\text { tempat } \\
\text { pelatihan, } \\
\text { menyediakan } \\
\text { bahan baku } \\
\text { pendukung } \\
\text { untuk } \\
\text { mensetting } \\
\text { tempat } \\
\text { peletakan } \\
\text { alat. }\end{array}$ & $\begin{array}{l}\text { Alat pencacah } \\
\text { singkong } \\
\text { banyaknya } 2 \\
\text { buah dengan } \\
\text { spsesifikasi } \\
\text { mampu } \\
\text { mencacah } \\
\text { singkong } \\
\text { dengan } \\
\text { kapasitas } \\
\text { produksi kira- } \\
\text { kira } 40 \mathrm{~kg} \\
\text { singkong/jam }\end{array}$ \\
\hline & $\begin{array}{l}\text { b) Produksi } \\
\text { belum sesuai } \\
\text { standart pasar } \\
\text { karena belum } \\
\text { bervariasi baik } \\
\text { dalam rasa } \\
\text { maupun warna, } \\
\text { kurang standard } \\
\text { dan kurang } \\
\text { higienis }\end{array}$ & $\begin{array}{l}\text { Pelatihan dan } \\
\text { pendampinga } \\
\text { n membuat } \\
\text { kripik } \\
\text { singkong } \\
\text { aneka rasa, } \\
\text { aneka warna } \\
\text { dengan } \\
\text { pewarna dan } \\
\text { perasa yang } \\
\text { alami dan } \\
\text { yang higienis }\end{array}$ & $\begin{array}{l}\text { Memberikan } \\
\text { ketrampilan } \\
\text { pada kelompok } \\
\text { usaha kripik } \\
\text { singkong } \\
\text { tentang } \\
\text { pembuatan } \\
\text { kripik } \\
\text { singkong } \\
\text { aneka rasa, } \\
\text { aneka warna } \\
\text { dengan warna } \\
\text { alami.. }\end{array}$ & $\begin{array}{l}\text { Menyediakan } \\
\text { atau } \\
\text { membawa } \\
\text { bahan yang } \\
\text { diperlukan } \\
\text { untuk } \\
\text { pelatihan, } \\
\text { menyiapkan } \\
\text { tempat. }\end{array}$ & $\begin{array}{l}\text { Peserta } \\
\text { (pengrajin } \\
\text { kripik } \\
\text { singkong) } \\
\text { mampu } \\
\text { mebuat } \\
\text { camilan } \\
\text { minimal } 3 \text { rasa } \\
\text { ( rasa asin, } \\
\text { gurih dan } \\
\text { original) }\end{array}$ \\
\hline 2. & $\begin{array}{l}\text { a) Pengemasan } \\
\text { masih sistem } \\
\text { sulut api } \\
\text { sehingga tidak } \\
\text { menarik }\end{array}$ & $\begin{array}{l}\text { Pelatihan dan } \\
\text { pendampinga } \\
\mathrm{n} \\
\text { mengemasan }\end{array}$ & $\begin{array}{l}\text { Pengadaan dan } \\
\text { pelatihan } \\
\text { pengemas dan } \\
\text { pelatihan } \\
\text { penggunaan } \\
\text { alat pengemas. }\end{array}$ & $\begin{array}{l}\text { Menyediakan } \\
\text { atau } \\
\text { membawa } \\
\text { bahan yang } \\
\text { diperlukan } \\
\text { untuk } \\
\text { pelatihan, } \\
\text { dan } \\
\text { menyediakan } \\
\text { tempat } \\
\text { pelatihan }\end{array}$ & $\begin{array}{l}\text { Peserta mampu } \\
\text { membuat } \\
\text { mengemas dan } \\
\text { menggunakan } \\
\text { alat } \\
\text { pengemas.. }\end{array}$ \\
\hline 3. & $\begin{array}{l}\text { Pemasaran } \\
\text { masih tradisonal } \\
\text { "door to door", } \\
\text { dari mulut ke } \\
\text { mulu, dijual } \\
\text { dengan cara }\end{array}$ & $\begin{array}{l}\text { Pembuatan } \\
\text { Web dan } \\
\text { outlet yang } \\
\text { menarik } \\
\text { penyuluhan } \\
\text { kiat-kiat }\end{array}$ & $\begin{array}{l}\text { Pemasaran on } \\
\text { line dan } \\
\text { membuat } \\
\text { jaringan } \\
\text { pemasaran } \\
\text { kripik }\end{array}$ & $\begin{array}{l}\text { Menyediakan } \\
\text { tempat } \\
\text { pelatihan, } \\
\text { computer. }\end{array}$ & $\begin{array}{l}\text { Pengolah } \\
\text { kripik } \\
\text { singkong } \\
\text { memiliki Web } \\
\text { dengan } \\
\text { tampilan yang }\end{array}$ \\
\hline
\end{tabular}




\begin{tabular}{|c|c|c|c|c|c|}
\hline & $\begin{array}{l}\text { curah biasa, } \\
\text { dampkanya } \\
\text { omzet penjualan } \\
\text { terbatas }\end{array}$ & $\begin{array}{l}\text { pemasaran } \\
\text { kripik } \\
\text { singkong. } \\
\text { Pelatihan dan } \\
\text { pendampinga } \\
\text { n mengelola } \\
\text { penjualan on } \\
\text { line lewat } \\
\text { web }\end{array}$ & $\begin{array}{l}\text { singkong } \\
\text { beserta outlet } \\
\text { singkong }\end{array}$ & & $\begin{array}{l}\text { menarik } \\
\text { sebagai sarana } \\
\text { untuk } \\
\text { pemasaran. } \\
\text { Peserta mampu } \\
\text { menggunakan } \\
\text { Web untuk } \\
\text { promosi, dan } \\
\text { transaksi }\end{array}$ \\
\hline 4. & $\begin{array}{l}\text { Limbah hasil } \\
\text { kripik singkong } \\
\text { belum } \\
\text { termanfaatkan } \\
\text { dengan baik, } \\
\text { sehingga } \\
\text { mengganggu } \\
\text { kesehatan } \\
\text { lingkungan. }\end{array}$ & $\begin{array}{l}\text { Pelatihan dan } \\
\text { pendampinga } \\
\text { n mengolah } \\
\text { limbah kripik } \\
\text { singkong } \\
\text { menjadi } \\
\text { camilan }\end{array}$ & $\begin{array}{l}\text { Memberi } \\
\text { ketrampilan } \\
\text { mengolah } \\
\text { limbah kripik } \\
\text { singkong } \\
\text { untuk camilan. }\end{array}$ & $\begin{array}{l}\text { Menyediakan } \\
\text { tempat } \\
\text { pelatihan dan } \\
\text { limbah kripik } \\
\text { singkong }\end{array}$ & $\begin{array}{l}\text { Peserta } \\
\text { memiliki } \\
\text { ketrampilan } \\
\text { mengolah } \\
\text { limbah kripik } \\
\text { singkong } \\
\text { untuk camilan }\end{array}$ \\
\hline
\end{tabular}

Pengabdian kepada masyarakat yang sedang dilaksanakan pada dua mitra yaitu Bapak Muhammad Aksin (ketua kelompok pengolah kripik singkong Bintang Jaya) yang beralamatkan di Desa Kedok Sumbergong RT. 42 RW. 7 Turen Malang dan dengan Ibu Masfufatun Nisak (ketua kelompok pengolah kripik singkong Panggungrejo) pada tahun 2017 yang beralamatkan di Desa Panggungrejo N0. 21 Gondanglegi Kabupaten Malang.

\section{HASIL DAN PEMBAHASA}

Pengabdian ini menghasilkan beberapa hal antara lain;

1. Desain logo dan kemasan sesuai dengan standarisasi UMKM (Awalnya logo hanya berisikan nama mama "merk" keripik dan logo produk, dengan menggunakan kertas photo copy.)

Kemasan yang dibuat sesuai dengan fungsi kemasan, antara lain;

a. Sebagai wadah yang memungkinkan diangkutnya suatu produk atau barang dari satu tempat ketempat yang lain atau dari produsen ke konsumen.

b. Melindungi produk yang dikemas dari pengaruh cuaca, benturan, tumpukan dan lainlain.

c. Memberikan informasi, brand image dan sebagai media promosi dengan pertimbangan mudah dilihat, dipahami serta diingat. Sehingga kebutuhan kemasan dalam memberi informasi menjadi bagian yang paling penting. Pemberian label dan merek pada makanan dan produk lain sangat penting sebagai pembeda terhadap pesaing sehingga desain kemasan agar tampil menarik dapat dikonsultasikan pada desainer kemasan.

Keuntungan dari dibuatkannya logo lan label kemasan yang baru adalah daya tarik dan daya jual produk menjadi meningkat 
2. Perbaikan pada kemasan terbukti dapat meningkatkan daya dan nilai jual produk. Awalnya produk hanya dijual dengan sistem kemasan besar $5 \mathrm{~kg}$ an dan kemasan $800 \mathrm{gr}$ dengan plastik yang tipis.

Keuntungan dari adanya kemasan baru ini adalah;

a. Produk yang dihasilkan kualitasnya tetap terjaga, karena produk menjadi lebih awet dan tahan lama karena kemasannya lebih kokoh dan terbuat dari kemasan yang diperuntukkan untuk pangan.

b. Produk yang dihasilkan kualitasnya tetap terjaga karena menjadi tidak mudah hancur.

c. Keuntungan dari penjualan produk meningkat, jika sebelumnya dijual kemasan $5 \mathrm{~kg}$ (Rp.15.000) dan 800 gr (Rp. 3000,-) sekarang dapat dijual 500 gr (Rp.4000,-). Atau secara umum keuntungan meningkat Rp. 21.000,- sampai Rp. 25.000,- per $5 \mathrm{~kg}$.

3. Analisis dan semua prasyarat yang dibutuhkan untuk mengurus perijinan PIRT dan depkes.

Syarat-syarat untuk mendapatkan sertifikat industri rumah tangga pangan (IRTP) adalah :

a. mengisi formulir pendaftaran ;

b. fotokopi KTP yang masih berlaku sebanyak 1 (satu) lembar ;

c. pas foto Berwarna terbaru ukuran 3 x 4 sebanyak 1 (satu) lembar ;

d. Menyertakan rancangan label makanan/ minuman yang mencantumkan : (1) Nama makanan/ minuman dan atau merk dagang, (2) Komposisi bahan yang digunakan,

(3) Berat isi/ Bersih, (4) Tanggal kadaluarsa : ditulis (5) Kode produksi, (6) Nama dan alamat perusahaan, (7) Nomor registrasi.

e. Stampel perusahaan ;

f. Denah lokasi produksi ;

g. Mengikuti penyuluhan makanan/ minuman ;

h. Survey lokasi.

4. pengurusan sertifikat industri rumah tangga pangan (IRTP) tidak dipungut biaya.Inovasi rasa yang menjadi beraneka ragam (gurih, asin dan original) mampu meningkatkan daya beli/daya saing produk. Jika awalnya 1 minggu terjual hanya $10 \mathrm{~kg}$ sekarang mampu terjual $15-20 \mathrm{~kg}$.

5. Pelatihan dan pengolahan kulit umbi, memberikan wawasan dan inovasi produk baru bagi mitra. Awalnya mitra hanya membuang kulit umbi untuk makanan ternak. Sekarang mitra menjual kulit umbi yang sudah diolah menjadi camilan ringan @ Rp.1000,-

6. Pemberian bantuan timbangan digital, memberikan beberapa keuntungan terkait kemudahan dalam menimbang produk yaitu menimbang menjadi lebih praktis dan cepat. Hasil timbangan juga lebih presisi dan akurat.

7. Pemberian bantuan spinner peniris minyak, memberikan beberapa keuntungan antara lain;

a. Mempercepat proses produksi, terutama dalam proses penirisan minyak goreng pada keripik. Proses penirisan menjadi dua kali lebih cepat dibandingkan penirisan tradisional menggunakan kertas bekas.

b. Kapasitas keripik yang dihasilkan menjadi lebih banyak dari yang biasanya $4 \mathrm{~kg} / \mathrm{jam}$ jika menggunakan cara tradisional meningkat menjadi sekitar $15 \mathrm{~kg} / \mathrm{jam}$. Ini berarti kapasitasnnya meningkat menjadi hampir 4 kali lipat. 
c. Penirisan minyak yang sempurna menjadikan makanan lebih awet, gurih dan renyah, sehingga makan tidak cepat apek.

d. Produk yang dihasilkan menjadi lebih sehat dan hygenis karena tidak menggunakan kertas bekas untuk meniriskannya. Kandungan minyak jenuhnyapun menjadi banyak berkurang sekitar 30 gr. Penirisan menggunakan cara tradisional menghasilkan 500 gr, sedangkan dengan menggunakan spinner peniris minyak menjadi 470 gr. Dengan kandungan minyak jenuh yang lebih sedikit maka makanan akan lebih sehat karena berbagai efek negatif dari minyak jenuh jauh berkurang.

Tabel 5.1 Perbandingan Kuantitas dan Kualitas Produk

\begin{tabular}{|c|l|c|c|}
\hline No & \multicolumn{1}{|c|}{ Variabel } & $\begin{array}{c}\text { Penirisan dengan Kertas } \\
\text { Bekas }\end{array}$ & Penirisan dengan Spinner \\
\hline 1. & Waktu & 20 menit & 5 Menit \\
\hline 2. & Kapasitas & $4 \mathrm{~kg} / \mathrm{jam}$ & $15 \mathrm{~kg} / \mathrm{jam}$ \\
\hline 3. & Netto & $500 \mathrm{gr}$ & $470 \mathrm{gr}$ \\
\hline
\end{tabular}

8. Pemberian bantuan perajang singkong dan talas otomatis mampu memberikan beberapa keuntungan kepada mitra yaitu;

a. Menghemat tenaga mitra karena mengunakan tenaga listrik dengan daya yang cukup rendah yaitu 200 watt dan mudah dioperasikan oleh mitra.

b. Kuantitas produksi mengalami peningkatan. Perajang otomatis ini mampu memproduksi $150-200 \mathrm{~kg} / \mathrm{jam}$. Sebelum menggukan perajang otomatis, mitra hanya mampu merajang $5-10 \mathrm{~kg} / \mathrm{jam}$.

c. Lebih aman digunakan oleh mitra. Sebelumya jari-jari mitra rentan tergores mata pisau perajang tradisional.

d. Konstruksi kuat dan hygenis karena terbuat dari stainless steel

e. Tingkat ketebalan irisan seragam dan rapi, sehingga kualitas produk yang dihasilkan lebih terjamin.

\section{KESIMPULAN}

Berdasarkan uraian hasil dan pembahasan maka dapat disimpulkan bahwa Program Kemitraan Masyarakat ini telah berhasil meningkatkan kuantitas dan kualitas produksi keripik. Hal ini tampak dengan meningkatnya omset, meningkatnya daya beli, meningkatnya jumlah produksi keripik yang dihasilkan.

\section{DAFTAR PUSTAKA}

Budiyanto, 2012, Perancang Mesin Perajang Singkong, Tugas Akhir, Universitas Yogyakarta Malang.

G Niemann, 1992, Elemen Mesin, (Anton Budiman: terjemahan), Erlangga: Jakarta.

Sato,Takesi, 2005, Menggabar Mesin Menurut ISO, Pradnya Paramita: Jakarta. 
Sularso, Suga, Kiyokatsu. 2002, Dasar Perencanaan Dan Pemilihan Elemen Mesin, Pradnya Paramita : Jakarta.

Winarko, W. A. Jufriadi \& H D. Ayu, 2017. Peningkatan Kapasitas Peternak Lele Tradisional Melalui Program Kemitraan Masyarakat, JPM (Jurnal Pemberdayaan Masyarakat), 2(2), 173-180

Yusri, 2017, Pengujian dan Perawatan Mesin Peniris Minyak untuk Gorengan-Gorengan, Tugas Akhir, Politeknik Negeri Padang. 